\title{
Exploration of the new management mode of "Student's organization and Party branch" party building by college and university students
}

\author{
Yu-xin XIA ${ }^{1, a}$, Xiao-yue $\mathrm{Wu}^{2, \mathrm{~b},{ }^{*}}$ \\ ${ }^{1}$ School of Business Administration, HOHAI University, Changzhou Jiangsu, 213022,China \\ ${ }^{2}$ School of Business Administration, HOHAI University, Changzhou Jiangsu, 213022,China \\ aemail: xiayuxin1998learn@163.com, bemail:1092209417@qq.com \\ ${ }^{*}$ Corresponding author:Xiao-yue Wu
}

Keywords: Party building, Student organization, Party branch.

\begin{abstract}
The student party branch is an important battle fort of the development of the party's Party-building work. With the increase of the student party members, how can the Party branch fully play the leading role and create more effective and sound party building management mode in this era when the traditional mode has exposed obvious disadvantages are of perfect practical significance. This article will explore the new party building by college and university students and management mode of "Party branch built on Student's organization" through its necessity and practical way,so that we can do better in university's party building and cultivating student cadres under the new circumstance and make efforts to create the new situation of college and university student's work.
\end{abstract}

\section{Introduction}

The group of college and university student cadres is a major force in promoting reform and maintaining stability in universities. Doing the college and university student cadres training work well is significant for ideological and political education, which helps guide the healthy growth of college and university students and constructs the civilized environment in campus and so on.

However, there are still some work need to be improved in the construction of today's college and university students' party branch and student party member troop. For example, some party branches lack vitality because of its monotonous education form, and the effect of party members' activities is unimpressive. Also, the whole group of college and university student party members is extremely important to improve the quality. Besides, innovation and research of party building lack a scientific and overall plan, which is difficult to form a long-term effective result. Thus, Today's management model still needs to be improved.

"The standard of student party building in colleges and universities", issued by the education ministry of Chinese Communist Party in February 2017,clearly put forward that in accordance with the principle of giving full play to the fighting fortress role of Party branches and the vanguard role of Party members,conducting Party members' education and management service activities, on the basis of setting up student Party branches according to grades or colleges (departments), and according to actual needs,exploring major project groups,research groups and student apartments, communities, and community organizations such as the establishment of Party organizations, to explore student party building work to the most active, most innovative organizations to expand, expand the coverage of the party, where there are student party members where there are student party organizations, where there are party organizations where there is a sound organizational life and the full play of the role of the party organization.

Ruan Junhua (Zhejiang University) and his team put forward building practical party branch in student society for expanding the party members' practice base and creating the new way to cultivate party members as a good supplement for a formal party branch. ${ }^{[1]}$ Zhou chao (Yangzhou University) and his team put forward building red student society on the basis of party branch. It will combine student party branch building and student society building organically ,making the education from student party members in student society activities as the extension and supplement for the education 
form student party branch, giving better play to the guidance ability of student organization and enriching the educational contents. ${ }^{[2]}$ Wang wenjie (Beijing University of Technology) and his team put forward the countermeasures of the party branch building in young student organization in colleges and universities under the practice of Beijing university of technology student union directly subordinating to the Party branch. ${ }^{[3]}$ Li Jingyu (University of Shanghai for Science and Technology) put forward that the implementation of the credit system in colleges and universities makes student society increasingly become a field for students inter-acting with each other. Additionally, he put forward the problems of college and university society party branch materialization construction. ${ }^{[4]}$

\section{Necessity of Party Branch Building in Student Organizations}

\subsection{Playing the Leading Role of Student Party Branch Fully}

Nowadays, the team of student cadres in colleges and universities as a whole is a good thing. It does a lot of work in education management, maintaining harmonious and stable campus and activating campus cultural atmosphere in colleges and universities, achieving a series of positive results. However, the team of student cadres in colleges and universities faces a series of new situations, new challenges and new requests and some parts of problems has been highlighted. The most highlighted problem is minimal participation and advancement with existing the trend of breaking away from masses of young students. Building student party branch on the basis of the student organization and making it become its political core can make up the defects of its low politics and be conducive to improve the ideological consciousness of students represented by student cadres and cultivate those student cadres who are advanced in thought and excellent in quality an study.

\subsection{Facilitating Student Party Branch of Management and Supervision}

Under traditional management mode of party building, student party members are scattered and organizational cohesion is obviously weak on account of the weakening of the class concept. Therefore, the management and supervision of the Party branch for organization members are not enough. Also ,the lack of solidarity results in low effect of management in party building and less motivation for party members to participate, but the interior of student organization has relatively strong cohesive force, which will make up for defects of student party members being scattered and promote contact and communication between members. Besides, because of clear division of student organization departments and small scale of each department, student party member cadres can do honest and efficient management and supervision work.Under the lead and guidance of key members of a student organization and student party members, the efficiency and quality of party branch work will be improved. Finally, the linkage mechanism between departments will make up for the defect of insufficient management members and largely improve the management efficiency.

\subsection{Acquiring the New Way of Party Building Education Activity Innovation}

As can be viewed above, student organization and student party branch have very strong complementary. Building the student organization party branch can carry out party building education work into the daily work of the student organization for innovating the new form of party building education activities. Also, it can integrate the ideological and political education into student organization activities, intensify the understanding of the party among organization members in activities, make the organization comprehensively investigate and cultivate party activists and improve the overall quality of party members. Additionally, it can advance the construction of school spirit and study spirit through carrying out various activities with strong learning ability. The innovative way of combining party building with student organization work and activities injects vitality and creativity into the development of party building in colleges and universities, which benefits improving working quality of the Party branch and the masses strengthening their supervision to party members to some extent. 


\section{Practical Approaches of Establishing Party Branch in Student Organization}

\subsection{Institutional Construction}

\subsubsection{The Situation of Hierarchical Responsibility}

The party branch of the student organization is led by the organization department of the party committee of colleges and universities, and the youth league committee carries out specific management. It must clarify the work responsibility of the party, the league and the student organization, and achieve flawless division of work and accurate assignment of tasks. The Party branch is the administrative core of the student organization.

\subsubsection{Publicizing the Guidance Documents and Standardizing the Work Comprehensively}

The organization department of the party committee in colleges and universities or the department in charge of education shall continue to make in-depth investigations, summarize and publish relevant basic documents, so as to provide the construction of party branch of student organization with the specific document spirit guidance ${ }^{[6]}$,promote the systematic, scientific and standardized work and also facilitate the supervision of the masses and the party organizations at the higher levels.

\subsubsection{Selecting Excellent Cadres}

In terms of the selection of party branch secretary, it can be considered to start training students from the junior grade and select suitable candidates through the allocation of basic party affairs. Student leaders with good work style, strong working ability and strong party spirit, such as chairman and minister can be given priority. In order to maintain the high level of the cadre team, regular ideological education and party work skills training should be given.

\subsection{4"Biweekly Meeting"of the Branch Democratic Life System}

The branch meeting should be held every two weeks to pay attention to the political trend. The student organization should study the state and school's new policy under the leadership of the party branch to be familiar with the theory principle and strengthen the members' party spirit. Besides, Special party class education should be started from the junior year to encourage students to criticize and self-criticize, let them report to the organization regularly and strengthen their communication with other members.

\subsection{Management and Supervision}

\subsubsection{Strengthening the Investigation and Training of Party activists}

Party branch of student organization should keep close contact with those party activists, understand their personal characteristics, strive to achieve targeted education to each activists, innovate education forms, and do a good job in various ways in cultivating party spirit and ideological and political education for party activities to provide high-quality talents for developing party members. With the increasing of party activists, the problems of declining management efficiency and quality must be strictly supervised. At this time, the role of student organization cadres should be given full play and a more detailed division of work should be carried out.

\subsubsection{Giving Full Play to the Political Core Role of the Party Branch}

As the political core of the student organization, first of all the student party branch should take the lead in ensuring that the party and the state and the school's policies are implemented with the actual situation. While assisting the student organization in completing various tasks, it should supervise the implementation of the policies of the organization members and give timely and effective criticism and correction to the bad style. Secondly, the party branch should constantly strengthen its own construction, and the party branch members should keep in close contact with the members of the student organization, striving to do a good job in the ideological and political education work of the student organization. Finally, the student party branch can participate in formulating major decisions related to the change of leadership, ideological construction of student organization and so on to make the work of the two more coordinated and ensure the quality of the student cadre teams, deepening the "one heart and double rings" work pattern. 


\subsubsection{Improving the Mass Supervision System over Party Members and Improving the Quality of Student Party Members}

In order to give full play to the supervision role of the masses and establish the supervision and evaluation system for the individual party members and their work, which is represented by the ordinary members of student organizations, quantitative indicators can be set, and regular inspection and feedback can be conducted to ensure that the student party members and student cadres truly and effectively "do practical work". Party organizations at the higher level should also receive regular feedback from the masses, give rectification opinions and supervision.

\subsection{Education Form Innovation in New Party Building Management Mode}

The student organization activities can be integrated with the party building activities on the basis of the new party building management mode of the party branch established by the student organization. First of all, the party branch's ideological guidance work can use students to organize activities such as excellent student communication meeting and celebrity lectures, which can greatly reduce the boredom of traditional ideological and political education model, add interest and interactivity, and improve students' participation. Secondly, the students' organization can carry out a wider range of communication activities, so that the members and universities are more closely connected with each other in party spirit cultivation and party building, which complement each other and makes common progress.

\section{Summary}

The student organization activities can be integrated with the party building activities on the basis of the new party building management mode of the student party branch is the bridge and the key link between the party and the young college students. It is the development need of The Times to explore the new college student party construction management model based on the student organization to establish the party branch. At present, some colleges and universities are doing relevant practices. To establish a sound and perfect party building management model, we need to conduct in depth research, summarize existing experience and find innovative approaches, and strive to achieve results in ideological guidance and organizational practice, so as to improve the education quality of student party members.

\section{References}

[1] Ruan Junhua, Shen Liyong, Jin Fangfang, Research and reflection on the party building of college student societies[J], Journal of China Youth University of Political Science, 2008(1):42-44.

[2] Zhou Chao, Sun Pengcheng, Li Weixing, A preliminary study on the establishment of red societies by relying on the party branch of college students[J], Journal of Yangzhou University(university research edition), 2009(2):27-29.

[3] Wang wenjie, Wang xiuyan, Hao rui, Study on the construction strategy of the party branch of young students in colleges and universities[J], Youth Studies in China, 2013(4):40-42.

[4] Li Jingyu, The path innovation of the materialized construction of the party branch of college societies[J],Party\&Government Forum, 2014(3):24-25.

[5] Chen Jianbo, Exploration and practice of party branch construction of university class[J], Journal of Lishui College, 2009,31(03):67-69.

[6] Zhu Huiqiong, Research on the construction of party branch of college students and classes[J], Journal of Inner Mongolia agricultural university (social science edition), 2008(05):296-298. 